\title{
First characterization of shark nursery habitat in the United States Virgin Islands: evidence of habitat partitioning by two shark species
}

\author{
Bryan M. DeAngelis ${ }^{1, *}$, Camilla T. McCandless ${ }^{1}$, Nancy E. Kohler ${ }^{1}$, \\ Conrad W. Recksiek ${ }^{2}$, Gregory B. Skomal ${ }^{3}$ \\ ${ }^{1}$ Apex Predator Investigation, NOAA, NMFS, 28 Tarzwell Dr., Narragansett, Rhode Island 02882, USA \\ ${ }^{2}$ University of Rhode Island, East Farm Building 50, Kingston, Rhode Island 02881, USA \\ ${ }^{3}$ Massachusetts Division of Marine Fisheries, Martha's Vineyard Field Station, PO Box 68, Vineyard Haven, \\ Massachusetts 02568, USA
}

\begin{abstract}
Little is known of the diversity, demography, and essential fish habitat of sharks within the United States Virgin Islands (USVI) marine ecosystem. To examine species diversity and the relative abundance of elasmobranchs in this region, bottom-longline and hand-gear sampling was conducted in Fish Bay, St. John, USVI, from June 2004 to December 2005. In the 8 sampling trips during this period, 54 standardized longline sets caught 174 elasmobranchs comprising 5 species of sharks and 1 batoid. Overall catch per unit effort $[\ln (\mathrm{CPUE}+1) \pm \mathrm{SE}]$ was $1.83 \pm 0.16$ elasmobranchs 100 hooks $^{-1} \mathrm{~h}^{-1}$. Lemon sharks Negaprion brevirostris had the highest relative abundance based on log-transformed CPUE data (0.98 \pm 0.15$)$, followed by blacktip sharks Carcharhinus limbatus $(0.91 \pm$ $0.18)$, southern stingrays Dasyatis americana $(0.28 \pm 0.08)$, nurse sharks Ginglymostoma cirratum $(0.08 \pm 0.05)$, blacknose sharks Carcharhinus acronotus $(0.06 \pm 0.04)$ and the Caribbean sharpnose Rhizoprionodon porosus $(0.03 \pm 0.03)$. The relative abundance of all species was significantly higher in the summer $(2.6 \pm 0.2)$ than during the winter $(1.1 \pm 0.2)$. For the blacktip $(\mathrm{N}=89$ captures of 74 individuals) and lemon ( $\mathrm{N}=66,48$ individuals) sharks, which comprised the bulk of the catch, mean fork length $( \pm \mathrm{SE})$ was $51.9 \pm 0.63 \mathrm{~cm}$ and $59.9 \pm 1.2 \mathrm{~cm}$, respectively, representing primarily neonatal and young-of-the-year life stages. The recapture rates for blacktip and lemon sharks were $21 \%$ and $29 \%$, respectively, and nearly all recaptures occurred within the bay, indicating a high degree of site fidelity. Capture information and limited acoustic tracking provided evidence of spatial and temporal habitat partitioning by these 2 shark species within the bay. Although the CPUE of both species was highest over shallow $(<1 \mathrm{~m})$ seagrass substrate, lemon sharks were found and tracked exclusively on shallow, mangrove-fringed seagrass habitat, while blacktip sharks utilized a wider area of the bay. Fish Bay was determined to provide important nursery habitat for young juvenile lemon and blacktip sharks in the USVI.
\end{abstract}

KEY WORDS: Shark nurseries · Blacktip shark $\cdot$ Carcharhinus limbatus $\cdot$ Lemon shark $\cdot$ Negaprion brevirostris $\cdot$ United States Virgin Islands

\section{INTRODUCTION}

The US Virgin Islands (USVI) is home to one of the richest coral reef ecosystems in the United States. Sharks represent an important component of the USVI marine ecosystem as apex predators and keystone indicators of coral reef productivity and health (Bas- compte et al. 2005). Although the reef fauna and reef fishes of the USVI are well studied (Caribbean Fishery Management Council 1985, Appeldoorn et al. 1992, Tobias et al. 1996, Rogers \& Beets 2001), little to no information exists on the diversity, demography, and essential fish habitat (EFH) of sharks around these islands. 
The West Indies shark fishery is considered an artisanal fishery, with landings typically consisting of locally or seasonally abundant species (Tobias et al. 2000). The commercial reef fishery in the USVI is a multi-species, multi-gear fishery with longline fishing being second only to trap fishing (Tobias 1997). According to the Department of Natural Resources, USVI fishermen often augment their harvest of inshore resources, which may include a variety of reef fishes and small coastal sharks, with offshore pelagic species, including large coastal and pelagic sharks (Meyers 1994). Although fishermen must adhere to the Final Consolidated Atlantic Highly Migratory Species Fishery Management Plan (NMFS 2006) when fishing in federal waters, there is currently no state or territorial management of sharks in the USVI. Instead, local management of elasmobranchs is accomplished indirectly through the protection of coral reef ecosystems or critical habitat for commercially important reef fishes. Research suggests that shark management must be accomplished at both the state and federal levels to ensure adequate protection (Camhi 1998, NMFS 1999).

Recent studies in the USVI indicate that coral reefs have experienced a transition from coral to algaldominated reefs (Rogers \& Miller 2006). There is theoretical support from Caribbean food-web models that the overfishing of sharks and other top predators may have contributed to this shift (Bascompte et al. 2005); local marine managers suspect that this is the case (Rogers \& Beets 2001), as the decline of reef fish fauna and top-level predators in the USVI is well documented (Appeldoorn et al. 1992, Tobias et al. 1996, Beets 1997, Tobias 2000).

Sharks are typically slow growing, K-selected species with low intrinsic rates of reproduction, rendering them vulnerable to overfishing (Holden 1974, Hoenig \& Gruber 1990, Pratt \& Casey 1990, Smith et al. 1998, Stone et al. 1998, Musick 1999, Cortés 2000). Given these life history characteristics, the delineation of shark nursery areas is critical for proper protection and management of these species (Casey \& Taniuchi 1990, Pratt \& Otake 1990, NMFS 2006). Shark nursery habitats often occur in coastal waters, which are high in food productivity (Castro 1987, 1993, Branstetter 1990, Rountree \& Able 1996), and in shallow waters where predation from adults is less likely (Springer 1967, Castro 1987, 1993, Branstetter 1990, Heupel \& Simpfendorfer 2002). Coastal nursery areas include bays (Hoese 1962, Castro 1993, Simpfendorfer \& Milward 1993, Merson \& Pratt 2001), estuaries (Snelson et al. 1984, Rountree \& Able 1996), and reef lagoons (Stevens 1984, Gruber et al. 1988). The Essential Fish Habitat Generic Amendment to the Fishery Management Plans of the U.S. Caribbean states that the waters and substrates that comprise EFH of the USVI are readily susceptible to a number of human activities, including overexploitation, sedimentation, pollution, marinas, and commercial and industrial development (Caribbean Fishery Management Council 1998). These anthropogenic activities may pose a risk to shark EFH in USVI coastal waters. It has been hypothesized that a limiting factor on shark populations is the amount of suitable nursery habitat available (Springer 1967).

In 2004, researchers from the National Marine Fisheries Service (NMFS) began conducting surveys of St. Thomas and St. John, USVI, to determine the demography and habitat use of elasmobranchs around these islands, with an emphasis on delineating shark nursery habitats (DeAngelis 2006). This paper reports on the findings from Fish Bay, St. John as a case study for similar habitats around the islands. The objectives of the study were (1) to assess elasmobranch species diversity and relative abundance within the bay; (2) to examine the extent to which Fish Bay is utilized as nursery habitat by shark species; and (3) to determine spatial and temporal habitat partitioning of the bay by blacktip and lemon sharks.

\section{MATERIALS AND METHODS}

Study site. St. Thomas $\left(51.5 \mathrm{~km}^{2}\right)$ and St. John $\left(32 \mathrm{~km}^{2}\right)$ are 2 of 3 major islands constituting the USVI. Pillsbury Sound, which divides these 2 islands, is located at $18^{\circ} 00^{\prime} \mathrm{N}, 64^{\circ} 49^{\prime} \mathrm{W}$. Both islands are hilly remnants of extinct volcanoes that rise from a submarine plateau. Consequently, the islands have narrow shelves (<16 km wide) and deep water (>2000 fathoms [3600 m] at deepest points) on the north and south sides. These edges bordering deep water are referred to as North and South Drops; they are popular fishing grounds. The coasts of both islands are characterized by long-shore bays with extensive coral reef areas and assemblages on the narrow shelf of the islands. More than three-fourths of the St. John coastline is part of the USVI National Park (Fig. 1) and the southeast corner of St. Thomas has been designated a USVI territorial marine reserve. Neither of these protected areas is a complete no-take zone.

Fish Bay is a relatively small bay on the south side of St. John (Fig. 1). It spans $490 \mathrm{~m}$ east to west, and $550 \mathrm{~m}$ north to south. The bay's bottom habitat is predominately continuous ( $>70 \%$ coverage) and patchy (50 to $70 \%$ coverage) seagrass, with some patchy $(<30 \%$ coverage) macroalgae. The mouth of the bay is bordered on both sides by a fringing reef. The eastern shore of the bay falls within the boundaries of the National Park; it is lined by partially submerged 


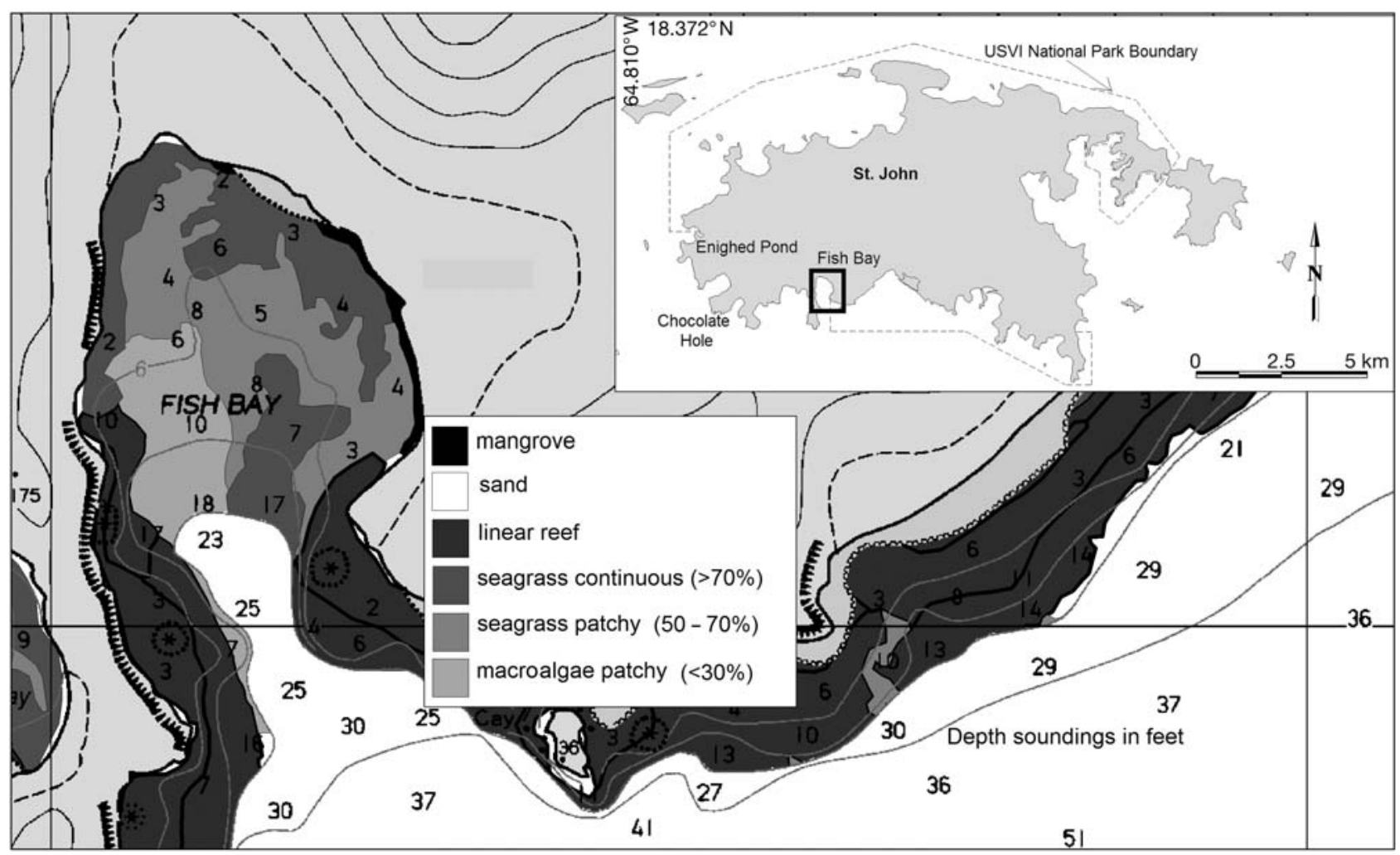

Fig. 1. Map of habitat distributions within Fish Bay with an inset of St. John, United States Virgin Islands

mangrove trees and the substrate comprises a very shallow $(<1.5 \mathrm{~m})$ seagrass bed extending approximately $140 \mathrm{~m}$ from the shoreline (referred to hereafter as the 'seagrass flat'). The seagrass flat slopes westward toward the center of the bay to depths ranging approximately 2 to $6 \mathrm{~m}$.

Sampling. Sampling in Fish Bay was conducted as part of a much larger survey of multiple bays in St. Thomas and St. John during June, July, and August of 2004, and January, March, May, July and December of 2005. During each trip, sampling took place in Fish Bay approximately 2 out of 8 d. In December 2005, Fish Bay was sampled during a period spanning $9 \mathrm{~d}$. The gear and sampling procedures used to survey sharks and other elasmobranchs in these areas were modeled after the methodology of the NMFS Cooperative Atlantic States Shark Pupping and Nursery (COASTSPAN) survey (McCandless et al. 2007). This included a 50-hook bottom longline comprising a $305 \mathrm{~m}, 0.64 \mathrm{~cm}$ diameter braided nylon mainline with gangions composed of size 12/0 circle hooks (O. Mustad \& Son A.S.) with barbs depressed; $50 \mathrm{~cm}$ of $0.16 \mathrm{~cm}$ diameter stainless cable compressed with metal compression sleeves; and $100 \mathrm{~cm}$ of $0.64 \mathrm{~cm}$ diameter braided nylon line attached to size $4 / 0$ longline snaps. The line was shortened to fish $<50$ hooks in areas that were too small to accommodate the entire longline. Hooks were baited with Atlantic mackerel
Scomber scombrus and the line was allowed to fish for $1 \mathrm{~h}$. In some instances, soak time was reduced to $0.5 \mathrm{~h}$ to minimize mortality of young sharks, especially blacktip sharks.

Sharks were also sampled using rod and reel on an opportunistic basis in July 2005. In addition, given the water clarity and shallow depths of sampling locations, visual observations of animals were sometimes recorded when species could be positively identified and it could be ascertained that the individual had not already been captured on the longline. Sharks that were visually observed or caught by rod and reel were excluded from the statistical analyses; only biological observations were used from those individuals.

Station locations, determined using a Global Positioning System (Garmin 12, Garmin International), sampling time, and depth were recorded at the start and end of each longline set. For statistical analyses, the average depth of the set was calculated from the 2 depth measurements. Other environmental conditions recorded for each set included: surface salinity (using an S/Mill E, Atago), wind-speed, wind direction, and cloud cover. When visual surveys were possible, bottom type was recorded and classified into one of 3 categories: unvegetated sand, macroalgae, and seagrass.

All species captured were identified to the species level, measured and released. For all elasmobranchs 
captured, sex, mass (kg), fork length (cm FL) and total length (cm TL) - or disk width (cm DW) for rays - was recorded. In addition, umbilical scar condition was noted for placental viviparous species and classified into 6 categories: umbilical remains, fresh open, partially healed, mostly healed, well healed, and none (Merson 1998). Before release, the first dorsal fin of most live sharks was hole-punched and tagged with a blue NMFS Rototag (Nettlebed, Dalton-Henly) or the dorsal musculature was tagged with a NMFS M-tag for larger sharks. The NMFS Apex Predators Investigation (Narragansett, RI) supplied these tags as part of the Cooperative Shark Tagging Program data and reward system, which archives this mark-recapture data (Kohler et al. 1998).

Individual sharks of each species were categorized into life stages based on published lengths at maturity (Clark \& von Schmidt 1965, Castro 1993, 1996, 2000, Henningsen 2000, Driggers et al. 2004), umbilical scar condition, and the degree of clasper calcification: young of the year (YOY; umbilical scar open or healed, but still visible), juvenile (healed umbilical scar; males with soft, uncalcified claspers and rhipidion not extensible, females based on length), and adult (males with hardened, calcified claspers, rhipidion extensible, females based on length). Some juvenile sharks were further classified as early juveniles by their small size and often faint presence of a healed umbilical scar. These results, in combination with catch-per-uniteffort (CPUE) data, length-frequencies, umbilical scar frequency of occurrence by month, mark-recapture data throughout the year, and acoustic tracking were used to quantify and examine the use of Fish Bay as nursery habitat. Mark-recapture data were used to quantify movements out of the bay and site fidelity.

Acoustic tracking. Between December 2, 2005 and December 10, 2005, 1 blacktip shark and 1 lemon shark were acoustically tracked in Fish Bay to monitor short-term horizontal movements and residency in the bay. The sharks were equipped with 54 and $51 \mathrm{kHz}$ ultrasonic transmitters (Model V16, Vemco), respectively. Each transmitter was attached to the first dorsal fin of the shark with nylon cable ties. The sharks were tracked using a directional hydrophone (Model V10, Vemco) wired to a portable receiver (Model V60, Vemco). During each track, it was assumed that the position of the tracking vessel roughly estimated the position of the shark when the receiver gain was low and the transmitter signal was strong in all directions. During the $9 \mathrm{~d}$ period, sharks were tracked intermittently for periods ranging from several minutes to $4.5 \mathrm{~h}$. Waypoints of the tracking boat and depth were determined using GPS and a digital depth sounder mounted on the vessel (Raymarine Model DS400X, Raymarine), respectively. In addition, water tempera- ture, salinity, and dissolved oxygen levels were measured at the surface and the bottom during each tracking interval using a water chemistry multiprobe (Model YSI 556 MPS, Yellow Springs International).

Tracking locations were plotted using GIS software (MapInfo Professional 7.0, MapInfo). Location of the shark was examined by day, depth, bottom habitat (density of seagrass), and water temperature. Tracking results were used to infer habitat preferences and to compare to results from the longline survey.

Data analysis. CPUE data were calculated to examine elasmobranch relative abundance within Fish Bay. Longline CPUE data, expressed as sharks 100 hooks $^{-1} \mathrm{~h}^{-1}$, were calculated by dividing the total number of elasmobranchs caught by total hook hours and multiplying by 100. CPUE data were log-transformed to normalize the distribution of the data $[\ln ($ CPUE + 1)] (Zar 1996, Maunder \& Punt 2004). Further analyses were conducted on the blacktip and lemon sharks to examine sex ratios and spatiotemporal changes in relative abundance. Chi-squared tests were used to test sex ratios for significant differences from a 1:1 ratio of males to females for both blacktip and lemon sharks. The $H_{0}$ for each test was that males and females should be present in equal proportions.

Locations of longline capture were plotted and described with GIS computer software (MapInfo Professional 7.0, MapInfo) utilizing the NOAA Benthic Habitat Maps of St. Thomas and St. John, USVI (NOAA 2001). Because of the general uniformity of salinity measurements (34 to 35 ) taken in Fish Bay, this variable was eliminated as a factor in statistical analyses of the blacktip and lemon shark CPUE data. Year was also not used as a potential factor due to the small number of years this time series has had to develop during this ongoing project. Season, depth, and bottom habitat, therefore, were the primary factors used in determining temporal and spatial habitat utilization of the bay. For these analyses, the bay was divided into 3 depth categories: 0-1 $\mathrm{m}, 1-3 \mathrm{~m}$ and 3-6 $\mathrm{m} ; 3$ bottom habitat categories: seagrass, sand and macroalgae; and the sampling months were pooled into summer (May, June, July, August) and winter (January, March, December) seasons. General linear models (GLM) were used to test for significant differences $(\alpha=0.05)$ in mean CPUE (log-transformed) among seasons, depth and bottom habitat categories for total, YOY and early juvenile blacktip and lemon sharks. For each species category (total, YOY, and early juvenile), separate GLMs containing a single potential factor were initially run to determine which factor should be used in the original model, based on the model containing the lowest $p$-value (of the $F$-ratio based on the residual mean square error), 
lowest Akaike's information criterion (AIC) and highest r-squared value. Models were then fitted in a stepwise forward manner, adding one potential factor at a time. The factors resulting in a reduction in the previous model's AIC and an increase in the model's Rsquared value by at least $2 \%$ were then incorporated into the model provided the resulting model was significant at the $\alpha=0.05$ level (Maunder \& Punt 2004). The final GLMs were followed by Fisher's least significant difference (LSD) multiple range tests to test for significant differences $(\alpha=0.05)$ in mean log-transformed CPUE among the independent categorical variables. All statistical procedures were performed in Statgraphics Plus 3.3 (Statistical Graphics).

\section{RESULTS}

\section{Catch rates}

Eight sampling trips were conducted from July 2004 to December 2005 around St. Thomas and St. John. During that time, a total of 54 standard longline sets were conducted in Fish Bay, with the number of sets relatively even across seasons (June, July, and August $2004=22 \%$, January and March $2005=22 \%$, May and July $2005=26 \%$, and December $2005=30 \%$ ). Nearly all $(96 \%)$ of the sampling took place during the day. A limited amount of rod and reel fishing took place in the bay in July 2005. Of the longline sets, $83 \%$ took place over seagrass, $11 \%$ over unvegetated sand, and $6 \%$ over macroalgae. Depth of sets varied within the bay, with $44 \%$ occurring in $<1 \mathrm{~m}, 43 \%$ occurring between 1 and $3 \mathrm{~m}$, and $13 \%$ between 3 and $6 \mathrm{~m}$. A total of 174 elasmobranchs, including recaptures, comprising 5 species of sharks and 1 batoid were taken on longline (Table 1). Mean log-transformed CPUE $( \pm \mathrm{SE})$ for standard longline sets was $1.83 \pm 0.16$ elasmobranchs 100 hooks $^{-1} \mathrm{~h}^{-1}$. Lemon sharks had the highest relative abundance based on log-transformed data (0.98 \pm $0.15)$, followed by blacktip sharks $(0.91 \pm 0.18)$, southern stingrays $(0.28 \pm 0.08)$, nurse sharks $(0.08 \pm 0.05)$, blacknose sharks $(0.06 \pm 0.04)$ and Caribbean sharpnose sharks $(0.03 \pm 0.03)$ (Fig. 2). Catch rates were significantly higher in summer $(2.6 \pm 0.2)$ than winter $(1.1 \pm 0.2, F=37.29, \mathrm{p}<0.01)$. Of the 168 elasmobranchs that could be classified into an age category, $97 \%$ were YOY or early juveniles.

Blacktip sharks ( $\mathrm{N}=89$ captures of 74 individuals) and lemon sharks ( $\mathrm{N}=66,48$ individuals) constituted the bulk of the total catch taken by standard and non-

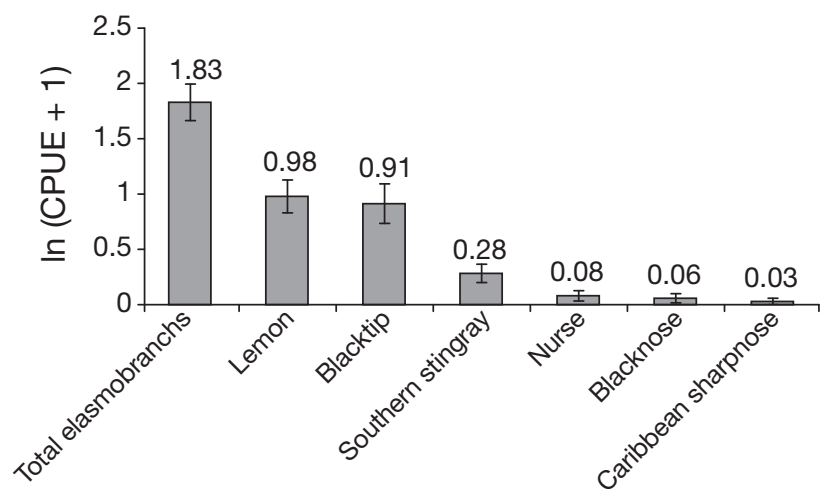

Fig. 2. Relative abundances based on log-transformed CPUE data for elasmobranchs captured in Fish Bay, St. John on longline sets from 8 sampling trips conducted June 2004 through December 2005

Table 1. Elasmobranchs recorded in Fish Bay, St. John, USVI during 8 sampling trips from June 2004 through December 2005. Number of individuals (N) includes fish recaptured once or more. FL: fork length; YOY: young of the year; juv: juveniles

\begin{tabular}{|c|c|c|c|c|c|c|c|c|c|c|c|c|}
\hline & \multirow[b]{2}{*}{$\mathrm{N}$} & \multirow[b]{2}{*}{ ㅇ } & \multicolumn{2}{|c|}{ - Total number } & \multirow{2}{*}{$\overline{\text { Recaptures }}$} & \multicolumn{2}{|c|}{ FL (cm) } & \multicolumn{2}{|c|}{ Depth (m) } & \multicolumn{3}{|c|}{ Age class } \\
\hline & & & $0^{7}$ & Unknown & & Mean & Range & Mean & Range & YOY & Juv & Adult \\
\hline $\begin{array}{l}\text { Blacknose } \\
\text { Carcharhinus acronotus }\end{array}$ & 3 & 3 & 0 & 0 & 0 & 78.5 & $57-105$ & 2.3 & $2.1-2.7$ & 0 & 2 & 1 \\
\hline $\begin{array}{l}\text { Blacktip } \\
\text { Carcharhinus limbatus }\end{array}$ & 89 & 39 & 47 & 3 & $17^{\mathrm{a}}$ & 51.9 & $42.5-77$ & 1.4 & $0.5-3.8$ & 76 & 10 & 0 \\
\hline $\begin{array}{l}\text { Caribbean sharpnose } \\
\text { Rhizoprionodon porosus }\end{array}$ & 2 & 1 & 0 & 1 & 0 & 41.3 & $40-42.5$ & 2.7 & N/A & 0 & 2 & 0 \\
\hline $\begin{array}{l}\text { Lemon } \\
\quad \text { Negaprion brevirostris }\end{array}$ & 66 & 38 & 26 & 2 & 18 & 59.9 & $50.3-83$ & 0.8 & $0.3-3.0$ & 39 & 24 & 0 \\
\hline $\begin{array}{l}\text { Nurse } \\
\text { Ginglymostoma cirratum }\end{array}$ & 3 & 2 & 1 & 0 & 0 & 168.9 & $125.5-244$ & 2.4 & $0.9-3.8$ & 0 & 2 & 1 \\
\hline $\begin{array}{l}\text { Southern stingray } \\
\text { Dasyatis americana }^{\mathrm{b}}\end{array}$ & 11 & 10 & 1 & 0 & N/A & 61.8 & $36-79$ & 1.6 & $0.6-3.8$ & 0 & 8 & 3 \\
\hline Total & 174 & 93 & 75 & 6 & 18 & & & & & 115 & 48 & 5 \\
\hline
\end{tabular}


standard methods. Although the observed male:female ratio for blacktip and lemon sharks was 1:0.8 and 1:1.6, respectively, neither ratio differed significantly from $1: 1$ ( $p>0.05)$. Mean fork length $( \pm S E)$ was $51.9 \mathrm{~cm} \pm$ $0.63 \mathrm{~cm}$ for blacktip sharks and $59.9 \mathrm{~cm} \pm 1.2 \mathrm{~cm}$ for lemon sharks (Fig. 3). The catch for both species included only neonatal, YOY, and early juvenile life stages.

Seasonal fluctuations in relative abundance of YOY and early juvenile blacktip and lemon sharks were observed in Fish Bay (Fig. 4). For both species, catch rates were greatest mid-summer, followed by a decline into fall and winter. These seasonal changes are driven by the YOY of both species; this is particularly true for blacktip sharks (Fig. 4, Table 2), where catch rates during the summer season were significantly higher than the winter season for YOY of both species (Fisher's LSD, $p<0.05$ ). Bottom habitat did not significantly affect YOY and early juvenile blacktip and lemon shark relative abundance in Fish Bay and was only determined to contribute to the variance in catch rates in the final model for early juvenile blacktip sharks (Table 2).

We found no significant differences in depth-stratified relative abundance indices for total and YOY blacktip sharks (Table 2), suggesting that depth is not a significant factor determining YOY blacktip shark habitat in Fish Bay. Depth did have a significant effect on early juvenile blacktip shark catch rates (Table 2). Early juvenile blacktip CPUE was significantly higher in the 1-3 $\mathrm{m}$ depth zone than in the $<1 \mathrm{~m}$ and $3-6 \mathrm{~m}$ depth zones (Fisher's LSD, p < 0.05).

Lemon sharks were almost exclusively found on the mangrove-fringed seagrass flat. The majority of lemon sharks were caught in the shallowest depth category (total lemon shark CPUE \pm SE: $1.5 \pm 0.23$ ); only a single lemon shark, an early juvenile female (77.5 cm FL), was captured in the deepest depth category. Early juvenile lemon sharks were found at all depths, but exhibited the highest relative abundance in the shallowest depth category. The relative abundance of YOY lemon sharks was considerably higher in the shallowest depth category $(1.14 \pm 0.24)$ than in the middle depth category $(0.14$ \pm 0.11 ). No YOY were found in the deepest depth category. These results were quantitatively supported by the GLM of lemon shark CPUE, which indi-

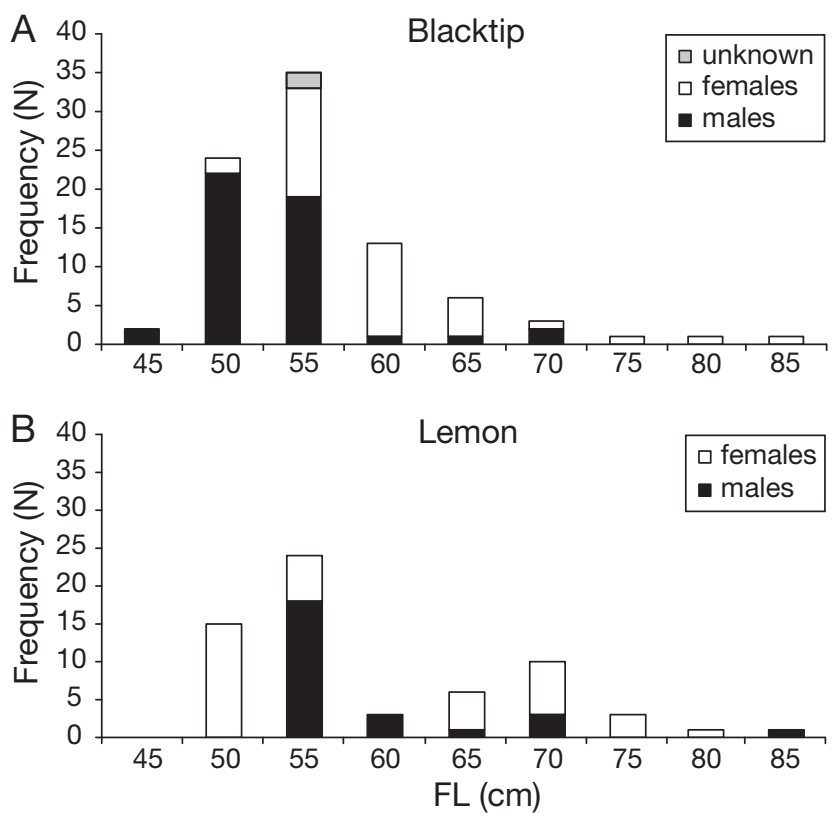

Fig. 3. Carcharhinus limbatus and Negaprion brevirostris. Length frequencies of (A) blacktip and (B) lemon sharks recorded in Fish Bay, St. John from 8 sampling trips conducted June 2004 through December 2005
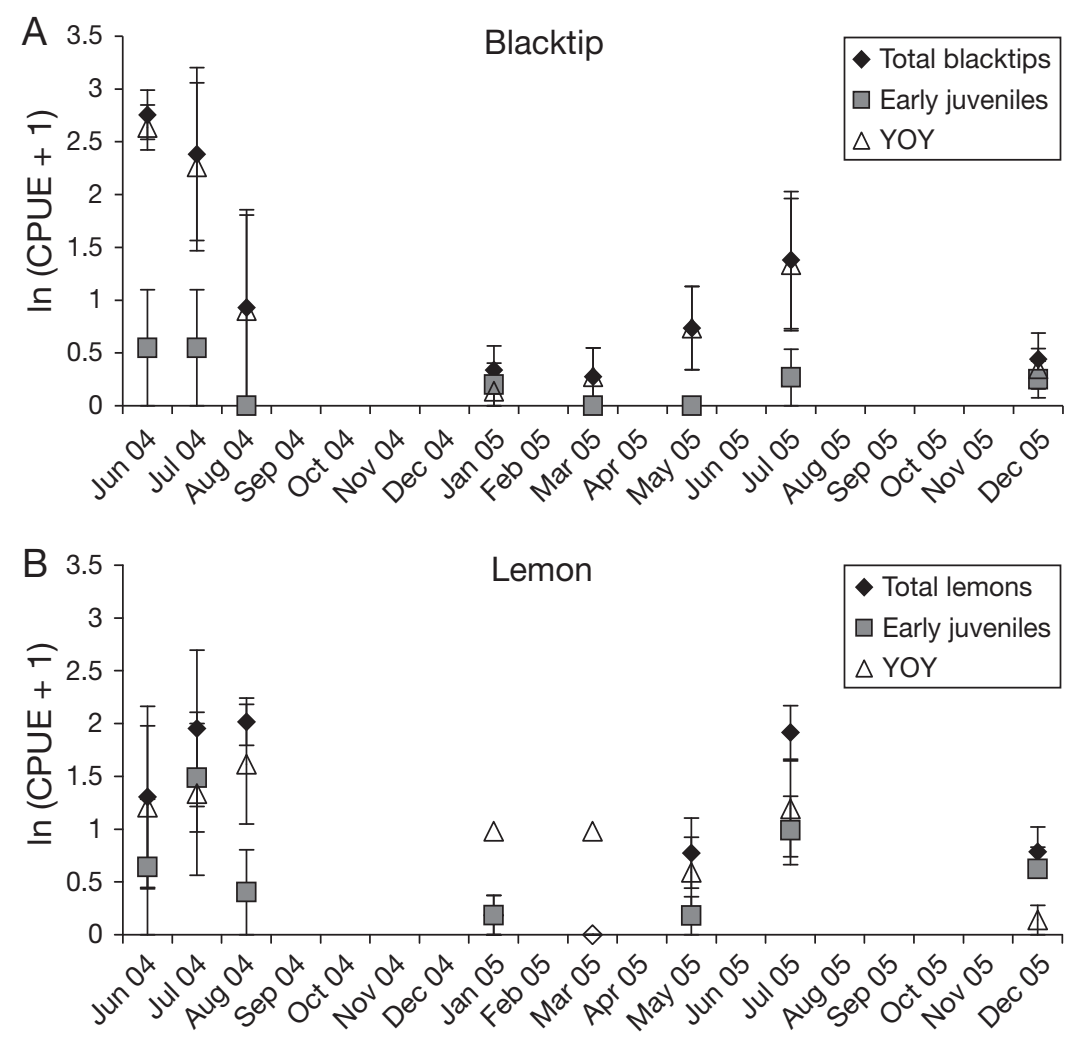

Fig. 4. Carcharhinus limbatus and Negaprion brevirostris. Relative abundance based on log-transformed CPUE data of (A) blacktip sharks and (B) lemon sharks captured on longline sets in Fish Bay, St. John from 8 sampling trips conducted June 2004 through December 2005 
Table 2. Carcharhinus limbatus and Negaprion brevirostris. Genral linear model (GLM) results for total, young-of-the-year (YOY), and early juvenile (early juv) blacktip and lemon sharks. Final models describe the factors that best explain the variance seen in catch rates for each of these groups. The first line under each group heading represents the final model ANOVA results with the associated Akaike's information criterion (AIC) and $\mathrm{R}^{2}$ values. The following lines represent the type III sums of squares results for the dependent variables that provided the best model fit to the data in each of the final models. The last line under each group represents the residuals for both the final model and type III sums of squares. SS: sum of squares; df: degrees of freedom. All F-ratios are based on the residual mean square errors

\begin{tabular}{|c|c|c|c|c|c|c|c|}
\hline & SS & df & $\begin{array}{c}\text { Mean } \\
\text { square }\end{array}$ & $F$-ratio & $\mathrm{p}$-value & AIC & $\mathrm{R}^{2}(\%)$ \\
\hline \multicolumn{8}{|c|}{ Total blacktip } \\
\hline Model & 16.02 & 1 & 16.02 & 11.19 & $<0.01^{*}$ & \multirow[t]{3}{*}{19.32} & \multirow[t]{3}{*}{17.71} \\
\hline Season & 16.02 & 1 & 16.02 & 11.19 & $<0.01^{*}$ & & \\
\hline Residual & 74.43 & 52 & 1.43 & & & & \\
\hline \multicolumn{8}{|c|}{ YOY blacktip } \\
\hline Model & 17.79 & 1 & 17.79 & 14.70 & $<0.01^{*}$ & \multirow{3}{*}{10.28} & \multirow[t]{3}{*}{22.04} \\
\hline Season & 17.79 & 1 & 17.79 & 14.70 & $<0.01^{*}$ & & \\
\hline Residual & 62.95 & 52 & 1.21 & & & & \\
\hline \multicolumn{8}{|c|}{ Early juv blacktip } \\
\hline Model & 4.95 & 5 & 0.99 & 3.06 & $0.02^{*}$ & \multirow[t]{5}{*}{-57.24} & \multirow[t]{5}{*}{24.16} \\
\hline Depth & 3.22 & 2 & 1.61 & 4.96 & $0.01^{*}$ & & \\
\hline Season & 1.25 & 1 & 1.25 & 3.85 & 0.06 & & \\
\hline Bottom & 1.31 & 2 & 0.65 & 2.02 & 0.14 & & \\
\hline Residual & 15.55 & 48 & 0.32 & & & & \\
\hline \multicolumn{8}{|c|}{ Total lemon } \\
\hline Model & 18.10 & 3 & 6.03 & 6.70 & $<0.01^{*}$ & \multirow[t]{4}{*}{-3.83} & \multirow[t]{4}{*}{28.68} \\
\hline Season & 5.42 & 1 & 5.42 & 6.02 & $0.02^{*}$ & & \\
\hline Depth & 4.89 & 2 & 2.44 & 2.71 & 0.08 & & \\
\hline Residual & 45.02 & 50 & 0.90 & & & & \\
\hline \multicolumn{8}{|c|}{ YOY lemon } \\
\hline Model & 18.64 & 3 & 6.21 & 9.14 & $<0.01^{*}$ & \multirow[t]{4}{*}{-19.00} & \multirow[t]{4}{*}{35.42} \\
\hline Season & 4.33 & 1 & 4.33 & 6.37 & $0.01^{*}$ & & \\
\hline Depth & 4.68 & 2 & 2.34 & 3.44 & $0.04^{*}$ & & \\
\hline Residual & 33.99 & 50 & 0.68 & & & & \\
\hline \multicolumn{8}{|c|}{ Early juv lemon** } \\
\hline Model & 0.94 & 1 & 0.94 & 1.42 & 0.24 & \multirow[t]{3}{*}{19.32} & \multirow[t]{3}{*}{17.71} \\
\hline Season & 0.94 & 1 & 0.94 & 1.42 & 0.24 & & \\
\hline Residual & 34.54 & 52 & 0.66 & & & & \\
\hline \multicolumn{8}{|c|}{$\begin{array}{l}{ }^{*} \text { Denotes significance at the } \alpha=0.05 \text { level } \\
{ }^{* *} \text { No significant models were found for early juvenile lemon sharks; the } \\
\text { model containing the highest } \mathrm{R}^{2} \text { value and the lowest AIC and } \mathrm{p} \text {-value } \\
\text { is reported here }\end{array}$} \\
\hline
\end{tabular}

ing on a cooperative study in the bay reported additional sightings of nurse sharks mating on the shallow seagrass flats near where this female was captured (R. Hill, NMFS, pers. comm.).

\section{Tag recaptures}

During this study, 64 blacktip sharks (57 YOY, 7 early juvenile) were tagged in Fish Bay and 14 (21\%) were recaptured; time between captures ranged from 4 to $511 \mathrm{~d}$. Three individuals tagged in Fish Bay were recaptured more than once (Table 3). With the exception of 2, all blacktip shark recaptures were taken in Fish Bay. The 2 sharks recaptured elsewhere had moved $2.1 \mathrm{~km}$ west (to Chocolate Hole, St. John) and $3.4 \mathrm{~km}$ west (to Enighed Pond, St. John) and were recaptured after 213 and $177 \mathrm{~d}$, respectively (Fig. 1). The tagged dorsal fin of the former shark was discovered freshly cut, lying on the beach by a local marine manager; it was assumed that the location and date of discovery of the fin was also the location and date of capture, but this may not be the case.

A total of 44 lemon sharks (24 YOY, 20 early juveniles) were tagged in Fish Bay and $16(29 \%)$ individuals were recaptured in Fish Bay; time between captures ranged from 1 to 139 d. Two individuals were recaptured more than once (Table 3 ).

\section{Acoustic telemetry}

A 58.3-cm-FL, early juvenile blacktip shark was intermittently tracked during daylight hours from 6 to 10 December 2005. The shark's location was recorded 114 times over the $5 \mathrm{~d}$ period $\left(\right.$ mean $=23 \mathrm{~d}^{-1}$, range $=1$ to $34 \mathrm{~d}^{-1}$ ). The shark was located

cated significant differences in depth-stratified relative abundance indices for YOY lemon sharks (Table 2). Multiple range tests revealed that mean YOY lemon shark CPUE in the shallowest depth category $(<1 \mathrm{~m})$ was statistically higher than those in the 2 deeper depth categories (Fisher's LSD, p < 0.05). The shallow seagrass flat on the eastern edge of the bay was used by additional elasmobranchs, including southern stingrays (mean depth $=1.6 \mathrm{~m}$ ). A single adult female nurse shark was also captured on the seagrass flat, in <1 m water in July 2005. Scientists work- in water depths ranging from 0.3 to $12.3 \mathrm{~m}$ (mean = $2.3 \pm 0.2 \mathrm{~m}$ ) (Fig. 5A). The shark was located in the 1-3 $\mathrm{m}$ depth category more than $50 \%$ of the time $(<1 \mathrm{~m}=$ $25 \%, 1-3 \mathrm{~m}=57 \%, 3-6 \mathrm{~m}=6 \%, 6-12 \mathrm{~m}=11 \%,>12 \mathrm{~m}$ $=1 \%)($ Fig. $5 \mathrm{~B})$. Water temperature at point of location ranged from 27.3 to $30.4^{\circ} \mathrm{C}$ (mean $=28.8 \pm 0.07$ ) (Fig. 5C).

Although the blacktip shark seemed to traverse Fish Bay in a circular pattern (Fig. 6), it was recorded most frequently in the northern portion of the bay. The tracking data indicate that the shark appeared to have 
Table 3. Carcharhinus limbatus and Negaprion brevirostris. Tag and recapture data from blacktip and lemon sharks tagged in Fish Bay, St. John during 8 sampling trips from June 2004 through December 2005. All recapture locations were in Fish Bay, unless otherwise stated. Distance measured in $\mathrm{km}$. For sharks recaptured a second time, commas separate values for initial mark to second recapture and first recapture to second recapture, respectively. nd: no data

\begin{tabular}{|c|c|c|c|c|c|c|c|c|c|c|}
\hline & - Tagge & - & & Recal & re 1 & & & Recar & ture 2 & \\
\hline & Tag date & FL & $\begin{array}{c}\text { Recapture } \\
\text { date }\end{array}$ & FL & $\Delta \mathrm{FL}$ & $\begin{array}{l}\text { Days at } \\
\text { liberty }\end{array}$ & $\begin{array}{l}\text { Recapture } \\
\text { date }\end{array}$ & FL & $\Delta \mathrm{FL}$ & $\begin{array}{l}\text { Days at } \\
\text { liberty }\end{array}$ \\
\hline Blacktip & $8 \mathrm{Jul} 04$ & 53.0 & 12 Aug 04 & 52.5 & -0.5 & 35 & & & & \\
\hline & 9 Jul 04 & 49.5 & 2 Jan 05 & nd & nd & 177 & & & & \\
\hline & 9 Jul 04 & 52.0 & $2 \operatorname{Dec} 05^{a}$ & 68.0 & 16.0 & 511 & & & & \\
\hline & 9 Jul 04 & 53.5 & 12 Aug 04 & 52.5 & -1.0 & 34 & & & & \\
\hline & 9 Jul 04 & 66.0 & 12 Jan 05 & 73.5 & 7.5 & 187 & & & & \\
\hline & 9 Jul 04 & 50.0 & 23 Jul 05 & 56.5 & 6.5 & 379 & & & & \\
\hline & 12 Aug 04 & 52.5 & $23 \mathrm{Jul} 05$ & 61.5 & 9.0 & 345 & & & & \\
\hline & 12 Aug 04 & 49.0 & 13 Mar $05^{\mathrm{b}}$ & nd & nd & 213 & & & & \\
\hline & 18 May 05 & 49.0 & $23 \mathrm{Jul} 05$ & 49.5 & 0.5 & 66 & & & & \\
\hline & 24 May 05 & 42.5 & $23 \mathrm{Jul} 05$ & 49.0 & 6.5 & 60 & 27 Jul 05 & 49.5 & $7,0.5$ & 64,4 \\
\hline & 24 May 05 & 48.0 & $23 \mathrm{Jul} 05$ & 49.0 & 1.0 & 60 & 27 Jul 05 & 48.5 & $0.5,-0.5$ & 64,4 \\
\hline & $23 \mathrm{Jul} 05$ & 51.0 & $27 \mathrm{Jul} 05$ & 50.5 & -0.5 & 4 & & & & \\
\hline & $23 \mathrm{Jul} 05$ & 49.5 & 27 Jul 05 & nd & nd & 4 & 6 Dec 05 & 53.2 & 3.7, nd & 136,132 \\
\hline & $23 \mathrm{Jul} 05$ & 48.0 & $27 \mathrm{Jul} 05$ & 48.5 & 0.5 & 4 & & & & \\
\hline Lemon & 13 Jun 04 & 55.0 & 1 Jul 04 & 54.0 & -1.0 & 18 & & & & \\
\hline & 8 Jul 04 & 51.5 & 9 Jul 04 & 51.5 & 0.0 & 1 & 16 Aug 04 & 51.5 & 0,0 & 39,38 \\
\hline & 8 Jul 04 & 53.0 & 12 Aug 04 & 52.5 & -0.5 & 35 & & & & \\
\hline & 9 Jul 04 & 55.0 & 16 Aug 04 & 52.5 & -2.5 & 38 & 18 Aug 04 & 52.5 & $-1,0$ & 40,2 \\
\hline & 9 Jul 04 & 53.5 & 18 Aug 04 & 52.0 & -1.5 & 40 & & & & \\
\hline & 18 May 05 & 51.7 & 23 Jul 05 & 50.5 & -1.2 & 66 & & & & \\
\hline & 24 May 05 & 51.0 & 23 Jul 05 & 50.3 & -0.7 & 60 & & & & \\
\hline & $23 \mathrm{Jul} 05$ & 56.0 & 6 Dec 05 & 59.6 & 3.6 & 136 & & & & \\
\hline & $23 \mathrm{Jul} 05$ & 52.5 & $27 \mathrm{Jul} 05$ & 52.5 & 0.0 & 4 & & & & \\
\hline & $23 \mathrm{Jul} 05$ & 53.5 & 9 Dec 05 & 59.4 & 5.9 & 139 & & & & \\
\hline & $23 \mathrm{Jul} 05$ & 56.0 & $27 \mathrm{Jul} 05$ & 57.2 & 1.2 & 4 & & & & \\
\hline & $23 \mathrm{Jul} 05$ & 58.5 & $27 \mathrm{Jul} 05$ & 58.5 & 0.0 & 4 & & & & \\
\hline & 4 Dec 05 & 67.1 & 10 Dec 05 & 67.1 & 0.0 & 6 & & & & \\
\hline & $23 \mathrm{Jul} 05$ & 71.0 & $27 \mathrm{Jul} 05$ & 71.0 & 0.0 & 4 & & & & \\
\hline & $23 \mathrm{Jul} 05$ & 73.5 & $27 \mathrm{Jul} 05$ & nd & nd & 4 & & & & \\
\hline & $23 \mathrm{Jul} 05$ & 75.0 & 6 Dec 05 & 74.9 & -0.1 & 136 & & & & \\
\hline
\end{tabular}

an aversion to the center of the bay, instead swimming along the north, east, and west coasts. There was no apparent preference for bottom substrate observed from the tracking results. The shark spent the majority of its time in the northern portion of the bay over continuous and patchy seagrass; however, it was also recorded over macroalgae, reef and sand. On 3 occasions, the shark left the protective enclosure of the bay before turning north and heading back into the bay. On all $5 d$, the shark spent most of its time in the northern corner of the bay, while occasionally swimming south along the coast and back. On 8 December 2005, however, the shark never left the northern corner. The wind was blowing hard from the south that day and the bay was murky.

An 80-cm-FL, early juvenile lemon shark was tracked for $5 \mathrm{~d}$ over a $7 \mathrm{~d}$ period, from 4 to 10 December 2005. The shark's location was recorded 30 times $\left(\right.$ mean $=6$ times $\mathrm{d}^{-1}$, range $=2$ to $\left.9 \mathrm{~d}^{-1}\right)($ Fig. $7 \mathrm{~A})$. This shark inhabited a depth range of 0.3 to $2.6 \mathrm{~m}$ and maintained an average depth of $1.1 \pm 0.12 \mathrm{~m}$ (Fig. 7B). The shark remained in water depths of $<1 \mathrm{~m}$ and 1 to $3 \mathrm{~m}$ for $58 \%$ and $42 \%$ of the track, respectively. Water temperature at point of location ranged from 26.2 to $29.7^{\circ} \mathrm{C}$ (mean = 28.2 \pm 0.2 ) (Fig. 7C).

The lemon shark was always recorded in the seagrass flat along the east coast of Fish Bay (Fig. 8). No preference for continuous or patchy seagrass can be inferred from the tracking locations. The relatively low number of observations may be attributed to the large amount of time that this shark was associated with the mangrove trees and in very shallow water. When swimming among the mangrove roots and in extremely shallow water, the acoustic signal was obscured and attenuated by the trees and the soft substrate; the shark could not be readily located. 

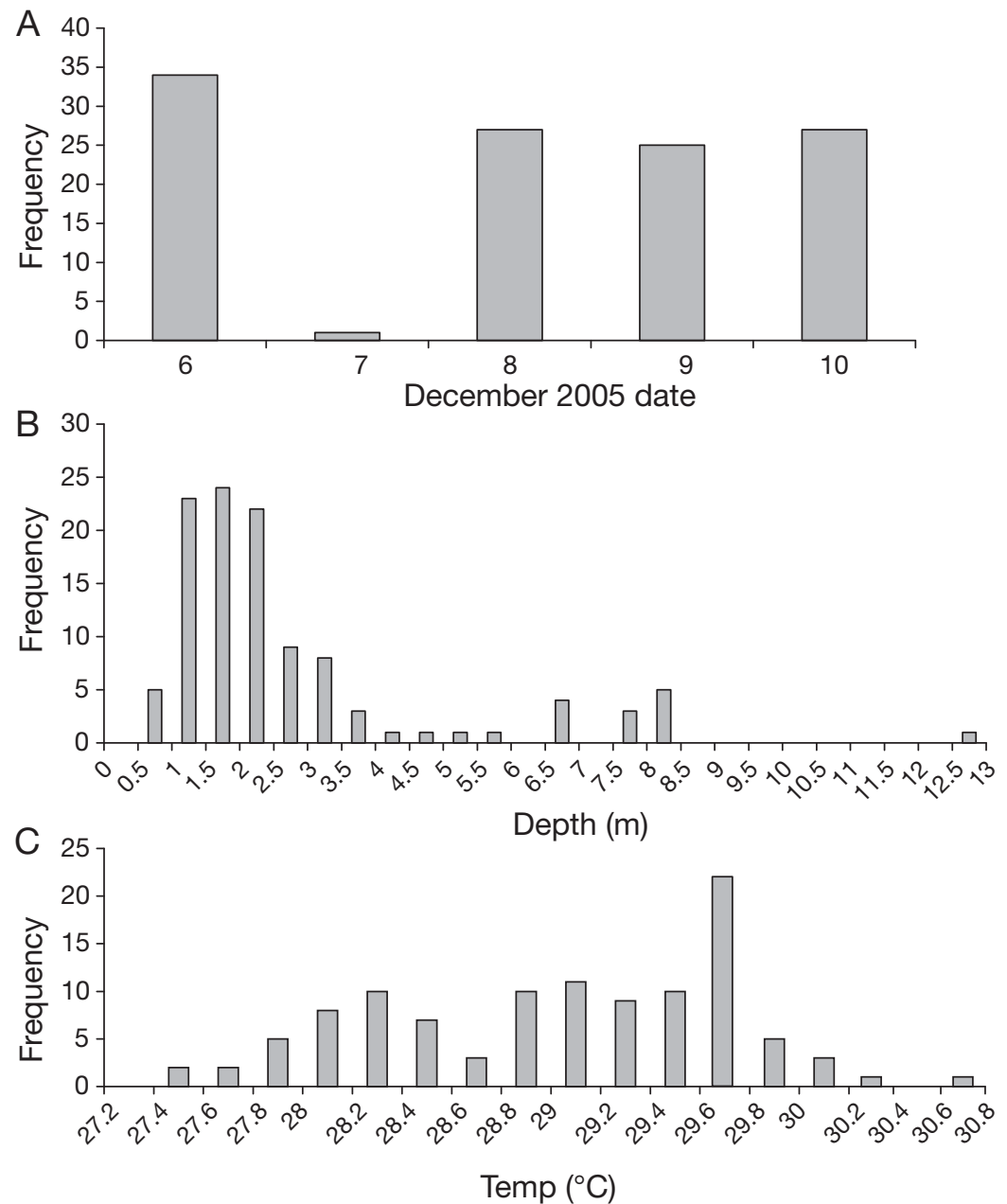

Fig. 5. Carcharhinus limbatus. Frequency of active acoustic tracking locations of a blacktip shark tracked in Fish Bay, St. John from December 6-10, 2005 by (A) date, (B) depth, and (C) water temperature

blacktip sharks have a wider distribution in the bay. Moreover, our observations, coupled with those of others (R. Hill pers. comm.), suggest that the seagrass flat on the east side of Fish Bay may be utilized as a nurse shark mating ground.

\section{Nursery area}

Neonate, YOY, and early juvenile blacktip and lemon sharks make up the vast majority of elasmobranch encounters in Fish Bay. Although the presence of neonatal sharks indicates that parturition may occur there, no pregnant females were recorded in the bay and it remains unclear if Fish Bay is used as a primary nursery as defined by Bass (1978). Heupel et al. (2007), however, suggest the distinction between primary and secondary nurseries is ambiguous and should be eliminated. Regardless, the size selectivity of our fishing method (for smaller sharks) may have biased our sampling and resulted in few adult captures. If parturition occurs outside of the bay, the young sharks almost certainly move in soon thereafter.

The use of Fish Bay as a nursery is further supported by the seasonal changes in YOY relative abundance, which peaked in mid to late summer and declined in mid winter. From this pattern, we can infer that parturition occurs in

\section{DISCUSSION}

The sampling conducted in 2004 and 2005 indicated that Fish Bay is utilized by at least 6 elasmobranch species, 5 sharks and 1 batoid. Fish Bay is a protected, enclosed bay with continually high relative abundance of juvenile blacktip and lemons sharks and provides nursery habitat for these 2 species. The significantly greater relative abundance of sharks in Fish Bay to that of other areas in the USVI (DeAngelis 2006), long-term site fidelity and continued use of the bay across years also meet the proposed criteria of Heupel et al. (2007) to distinguish Fish Bay as a shark nursery. Fish Bay can be partitioned into 2 zones, the very shallow, mangrove-fringed, seagrass flat on the eastern edge of the bay, and the seagrasslined deeper portion of the bay west of the flat. YOY and early juvenile lemon sharks exclusively utilize the seagrass flat, whereas YOY and early juvenile spring and summer, which is the timing of parturition documented for blacktip and lemon sharks in the southeastern USA and the Bahamas (Castro 1993, 1996). Although our tagging was not designed as a mark-depletion experiment, the seemingly high emigration and/or mortality rate at the end of summer is similar to that reported for blacktip and lemon sharks in Florida and the Bahamas (Heupel \& Simpfendorfer 2002, Gruber et al. 2001). However, these seasonal differences in relative abundance may also be driven by changes in catchability. Our observations of voracious feeding by young blacktip sharks in Fish Bay are similar to those reported for Terra Ceia Bay, Florida (Heupel \& Simpfendorfer 2002), thereby suggesting that neonatal sharks are not overly selective and will readily consume bait. As these animals get older, they may become more difficult to capture, possibly because of reduced feeding or increased selectivity in diet (Heupel \& Simpfendorfer 2002). 

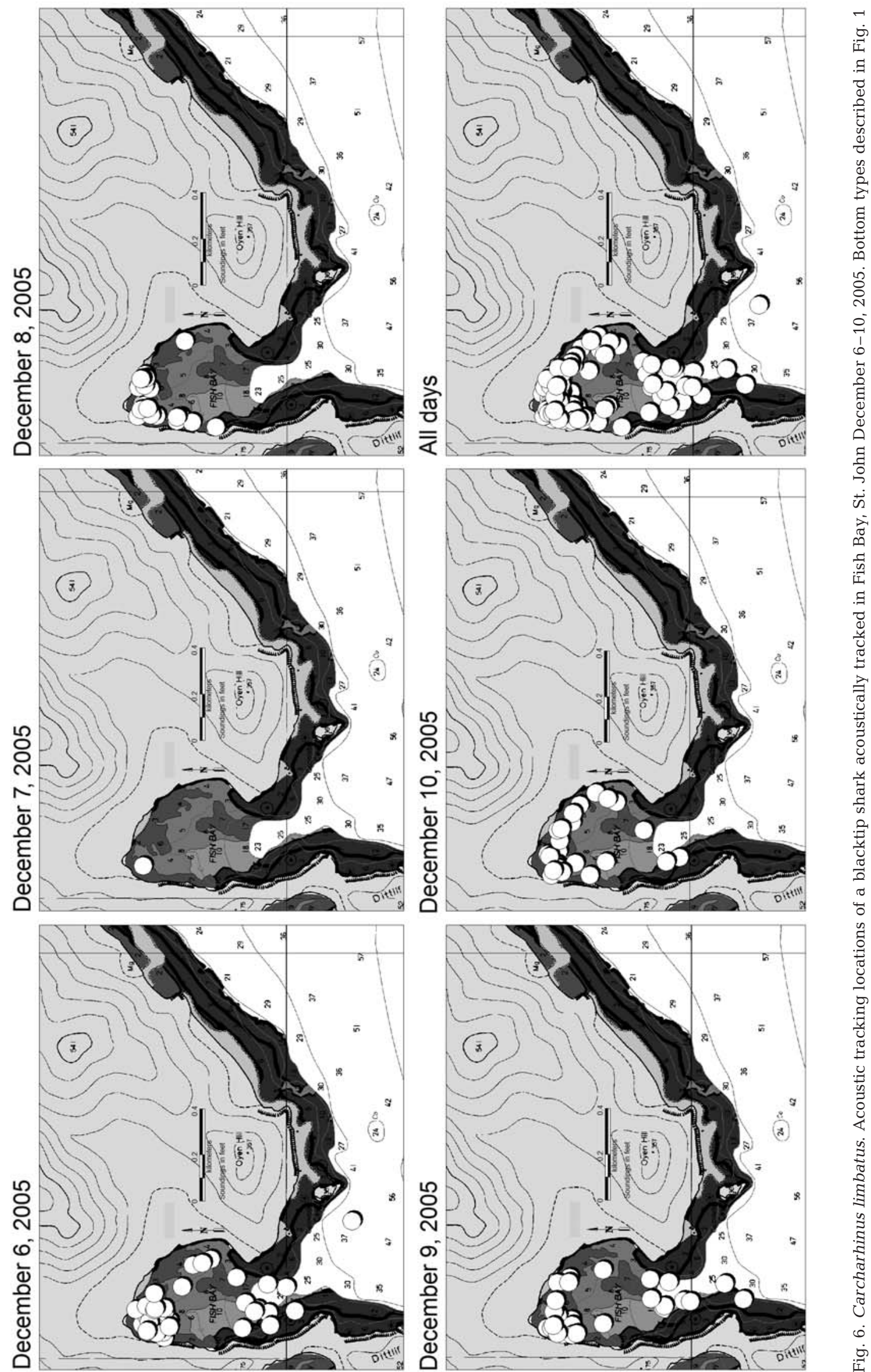

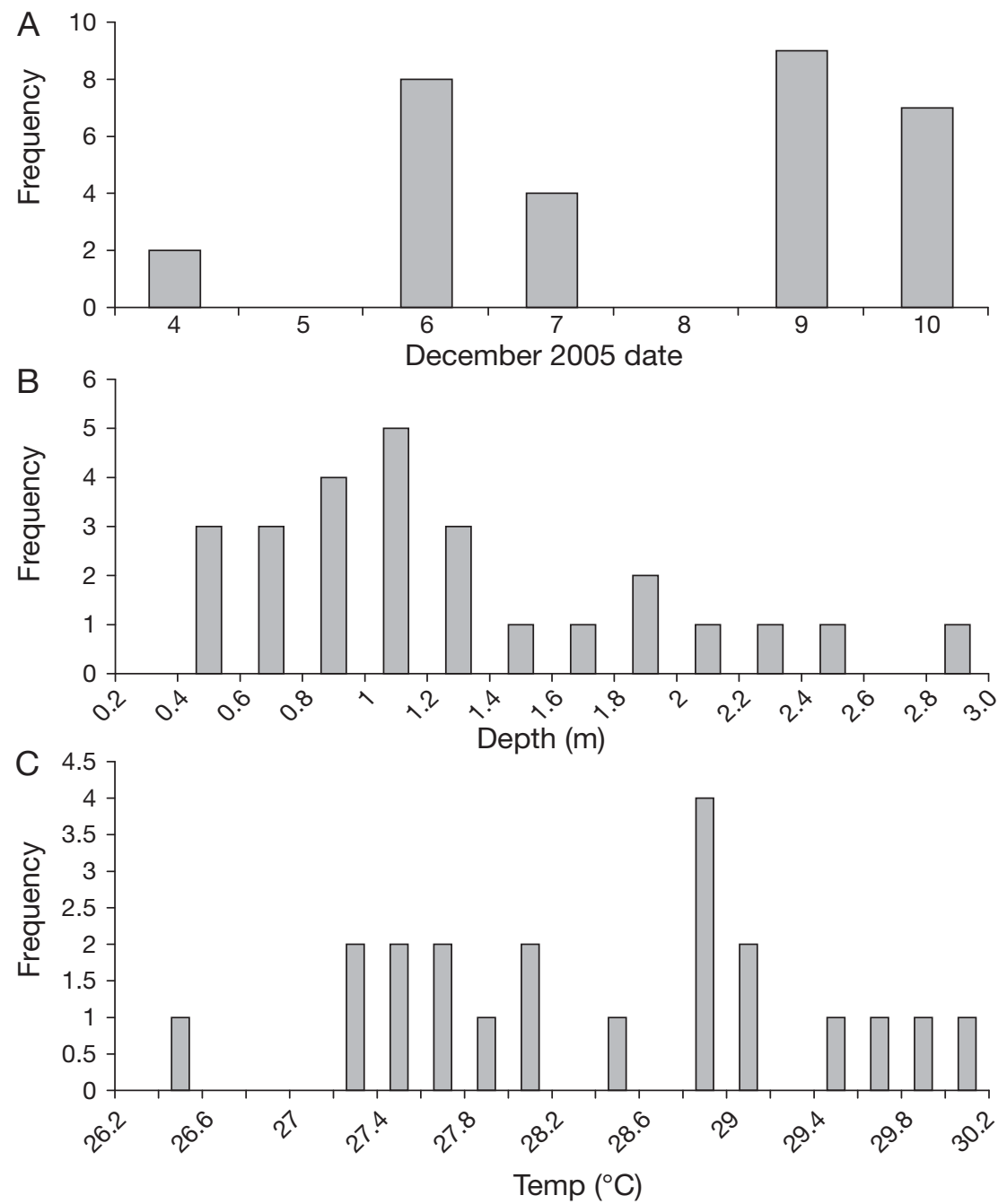

Fig. 7. Negaprion brevirostris. Frequency of active acoustic tracking locations of a lemon shark tracked in Fish Bay, St. John from December 4-10, 2005 by (A) date, (B) depth, and (C) water temperature

The recapture of neonatal blacktip and lemon sharks in Fish Bay each month of the summer provided evidence of a moderate degree of site fidelity. Recaptures of approximately a year and more illustrate long-term site fidelity and provide confirmation that Fish Bay provides nursery habitat for young juvenile blacktip and lemon sharks. Long-term fishery independent surveys in putative shark nursery habitat, such as this ongoing tagging survey being conducted in the USVI, are essential to help determine the importance of these areas in supporting juvenile shark populations (McCandless 2007).

\section{Habitat use and partitioning}

The standard longline sampling that we conducted indicated that there was some age-specific habitat sepa- ration between lemon and blacktip sharks in Fish Bay. Neonatal and YOY lemon sharks were rarely observed outside the shallow seagrass flat along the east side of the bay, and were never observed in the deepest depth zone of the bay $(>3 \mathrm{~m})$. We found some evidence of age-specific habitat partitioning in this species as early juvenile lemon sharks exhibited a higher relative abundance in the deeper depths than did the neonates and YOY. Hence, lemon sharks seem to broaden their habitat use into deeper depths as they get older. Such an ontogenetic expansion of home ranges by lemon sharks has been documented in Bahamian nurseries (Gruber et al. 1988).

Depth is a major determinant of habitat use by young lemon sharks in Fish Bay. Although the relative abundance of lemon sharks in our study was also highly correlated with the presence of seagrass beds, bottom substrate was not found to be a statistically significant factor determining lemon shark presence. We observed lemon sharks in very shallow sand patches with little or no seagrass, but never utilizing deeper habitats with heavy seagrass beds. Morrissey \& Gruber (1993) concluded that depth plays a significant role for young lemon sharks in the Bahamas and suggested that young lemon sharks remain in shallow water to avoid their major predators. Although Morrissey \& Gruber (1993) observed an apparent aversion to seagrass, which is contrary to our results, this supports our contention that depth is more important than bottom habitat. Fish Bay and other areas in the USVI that contained young lemon sharks (DeAngelis 2006) were typically associated with red mangrove trees Rhizophora mangle. Morrissey \& Gruber (1993) also suggested that mangrove environments may be attractive to the young sharks due to the abundance of prey contained in them and as a means of predator avoidance. In both studies, lemon sharks were witnessed swimming many meters from the shoreline, but always remaining in shallow water, suggesting that water depth and, hence, predator avoidance, plays a major role in habitat selection.

Blacktip sharks used a much broader depth range than lemon sharks and a much larger area of Fish Bay. The relative abundance of YOY blacktip sharks was not significantly higher in the shallowest depth zones than 

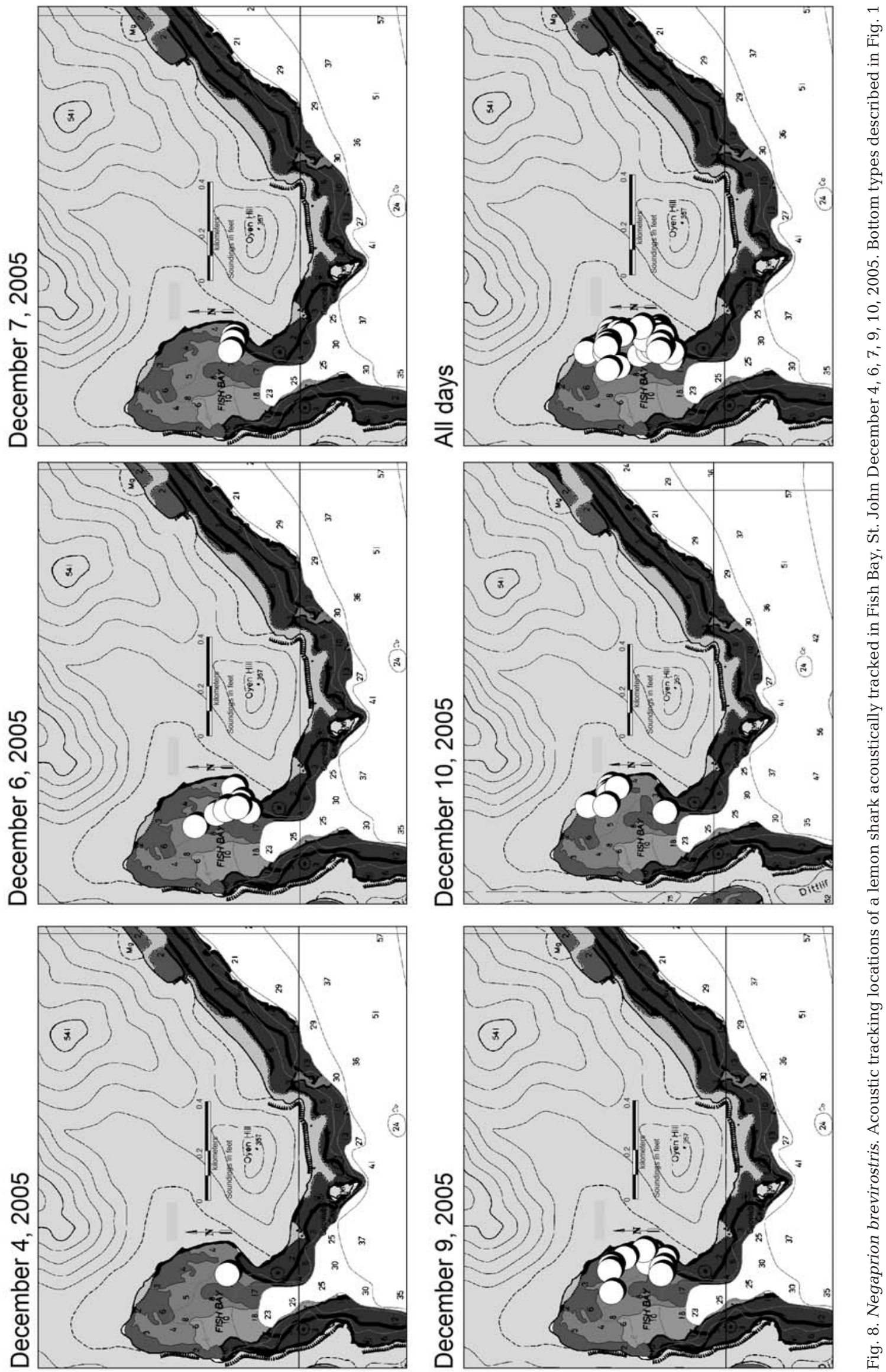
in the greater depths. Research on blacktip shark nurseries in Florida suggests that predator avoidance is the primary habitat criterion for these animals (Heupel \& Simpfendorfer 2002), even more so than available prey density (Heupel \& Hueter 2002). Although Fish Bay has relatively deep areas ( 6 $\mathrm{m})$, it is a small embayment with a narrow mouth. Therefore, Fish Bay differs markedly in size from other well-studied embayments characterized by high levels of predators (e.g. Shark Bay, Western Australia, Heithaus 2001). In Fish Bay, it is likely that young blacktip sharks can elude larger sharks by moving quickly into the shallow depth zone. Although we found that YOY blacktip sharks utilized a wide range of depths, we did not capture early juveniles in the shallowest parts of the bay. It is possible that YOY blacktip sharks remain in shallow areas and increase their depth range within the bay as they get older. Seagrass density does not appear to influence habitat usage as blacktip sharks were caught in the dense seagrass on the eastern and western edges of the bay as often as in the areas of less dense seagrass.

Data collected from acoustically tracked blacktip and lemon sharks provide independent support for our conclusions derived from longline data. It should be noted, however, that tracking data are limited by the low sample size. Hence, we have exercised caution when interpreting these data. The lemon shark was never observed leaving the seagrass flat on the eastern edge of the bay. This animal did not appear to have a preference for seagrass density, or for staying close to the mangrove prop roots. Acoustic location data for this lemon shark were consistent with the longline data, indicating that depth was the most influential factor determining the shark's location. The acoustically tracked blacktip shark was observed in a variety of depth categories and bottom habitat types in Fish Bay, a result similar to that derived from the longline data. Tracking data suggest that the shark had a preference for the northern corner of the bay. Heupel et al. (2004) demonstrated that blacktip sharks in a Florida nursery have a small, restricted home range that they use on a daily basis. In addition, the repetitive lap-like movements of the blacktip shark in this study have been observed in other nurseries (Heupel et al. 2004, Morrissey \& Gruber 1993). The shark in this study ventured outside the mouth of the bay on 3 occasions. These observations are consistent with those of Heupel et al. (2004), who suggested that young blacktip sharks maintain a core refuge area to avoid predation, but make excursions outside that area, possibly to feed. The tendency of this shark to avoid the deeper center of the bay possibly could be a means of predator avoidance from other sharks. Also, by keeping to the sides of the bay, the shark might limit the likely direction of an attack.
Fish Bay is the most significant blacktip and lemon shark nursery recorded in the USVI to date and longterm site fidelity is apparent for both species. Our understanding of habitat and resource partitioning between the species is incomplete. Simpfendorfer \& Milward (1993) recognized the lack of information on areas that are used communally by more than one species as a nursery. In their work, they identified possible advantages and disadvantages of communal nurseries. If several species of sharks utilize the same nursery, the adults of those species should tend to avoid that area (Springer 1967). Communal nursery areas should, therefore, provide a low predation environment for juveniles. A disadvantage may be increased competition for resources when compared to an area utilized by a single species.

\section{Management implications}

Unlike much of the shark nursery habitat in US tropical waters, the USVI are not characterized by extensive shallow flats and large, protected shallow bays. The few areas that do exist are very small, and therefore unlikely to support a high number of sharks given inter- and intra-specific competition (Simpfendorfer \& Milward 1993). As a result, protection of the limited nursery habitat that exists is crucial to sustaining shark populations in this region. Rogers \& Beets (2001) reported on the various stress factors currently affecting the USVI coral reefs, seagrass beds, and mangroves. Hurricanes, coral diseases, and unrestricted development have cumulatively caused severe, potentially non-reversible damage to these crucial habitats. Boulon (1992) and Tobias et al. (1996) reported on the importance of USVI mangroves as important habitat for various teleost species, which are the main prey items for young blacktip and lemon sharks (Cortés \& Gruber 1990, Heupel \& Hueter 2002, Hoffmayer \& Parsons 2003). The mangrove habitats of the USVI have been drastically altered by anthropogenic influences, including marinas, anchorages and coastal development (Tobias et al. 1996).

Fishing pressure on young sharks around St. Thomas and St. John is another issue that must be addressed to ensure sustainable management of these species. Sharks are not typically targeted by commercial fishermen, but recreational fishermen report that they often target and kill young sharks near shore for food (B. M. DeAngelis unpubl. data). Moreover, young sharks are preferred because they are readily available and easy to catch on handlines in shallow water without the use of a boat. During one sampling day (July 2005) in Fish Bay, nearly every YOY and early juvenile lemon shark that was observed had a hook in its jaw, indicating that 
recreational fishermen had caught nearly all the sharks and cut the line to release them. Although this may be indicative of high post-release survivorship, it also demonstrates the ease with which a few people could severely impact the largest recorded juvenile lemon shark aggregation in St. Thomas and St. John.

The eastern edge of Fish Bay, which encompasses the bulk of lemon shark nursery habitat in the bay, falls within the boundary of the USVI National Park. Fishing is allowed in the park with hook and line, traps of conventional Virgin Island design, and small seine nets. Because of the life history characteristics of sharks, the limited shark nursery habitat that exists must be protected to the fullest extent. These findings support the suggestion of Rogers \& Beets (2001) that National Park waters be converted to a no-take marine reserve. The expansion of the southwestern park boundary to encompass Fish Bay in its entirety would also encompass blacktip shark nursery habitat. In addition, stricter fisheries enforcement is needed to protect those sharks living outside the boundaries of the park and under the legal size limit from fishing mortality.

Preliminary investigations of shark nursery habitat around St. Thomas and St. John document habitat too limited to support large numbers of young coastal sharks (DeAngelis 2006). Protection of the existing shark nursery habitat and the sharks that utilize those areas is, therefore, critical to the long-term conservation of these ecologically important species. Shark nurseries of the USVI need further investigation to delineate nursery habitat, to quantify the importance of those areas to individual species, to quantify, in a spatial and temporal sense, the use of these areas by young sharks, and to assess the protection afforded to those areas by marine reserves.

Acknowledgements. We thank the organizations who made this work possible through their financial support: NOAA Coral Reef Conservation Program (award NAO4NMF46330 343), University of Puerto Rico Sea Grant PD-259, New England Biolabs Foundation, NOAA Center for Sponsored Coastal Ocean Research, University of Puerto Rico (award NA17OP2919), Project AWARE, NMFS Highly Migratory Species Management Division, Silver Spring, MD, and the many in-kind donations from the people of St. Thomas, St. John, and St. Croix. Thank you to the marine managers of the USVI who have helped and supported this work: R. Boulon, B. Kojis, W. Tobias. Much appreciation to S. McCandless for his contributions to this manuscript and his time in the field, as well as B. Gervelis, D. McElroy, J. Kneebone, and C. Scochi for their volunteered time in the field. We thank the Boston University Marine Program for funding the acoustic tracking portion of the study and, specifically, Melissa Giresi, Clare Hansen, Kristina Karl, and Sharinaz Maamor for assisting with the tracking. Lastly, thank you to the authors' many friends and family, and the kind people of St. Croix, St. Thomas and St. John who have supported this work in various ways.

\section{LITERATURE CITED}

Appeldoorn R, Beets J, Bohnsack J, Bolden S and others (1992) Shallow water reef fish stock assessment for the Caribbean. NOAA Tech Report NMFS - SEFSC 304, p 70

Bascompte J, Melian C, Sala E (2005) Interaction strength combinations and the overfishing of a marine food web. Proc Natl Acad Sci USA 102:5443-5447

Bass AJ (1978) Problems in studies of sharks in the Southwest Indian Ocean. In: Hodgson ES, Mathewson RF (eds) Sensory biology of sharks, skates and rays. Office of Naval Research, Department of the Navy, Arlington, p 545-594

Beets J (1997) Can coral reef fish assemblages be sustained as fishing intensity increases? In: Lessios HA, Macintyre LG (eds) Proc 8th Int Coral Reef Symp 2. Smith Trop Res Inst, Balboa, p 2009-2014

Boulon RH Jr (1992) Use of mangrove prop root habitats by fish in the northern Virgin Islands. In: Goodwin MH, Kau SM, Waugh GT (eds) Proc Gulf and Carib Fish Inst 41. South Carolina Sea Grant Cons, Charlestown, p 189-204

Branstetter S (1990) Early life history implications of selected carcharhinoid and lamnoid sharks of the northwest Atlantic. NOAA Tech Report NMFS 90:17-28

Camhi M (1998) Sharks on the line - a state-by-state analysis of sharks and their fisheries. Living Oceans Program, National Audubon Society, Islip

Caribbean Fishery Management Council (1985) Fisheries management plan, final environmental impact statement, and draft regulatory impact review for the shallow-water reef fish fishery of Puerto Rico and the US Virgin Islands. San Juan, Puerto Rico, USA

Caribbean Fishery Management Council (1998) Essential fish habitat (EFH) generic amendment to the fishery management plans of the U.S. Caribbean including a draft environmental assessment. Vol 1. San Juan, Puerto Rico

Casey JG, Taniuchi T (1990) Recommendations for future shark tagging programs. NOAA Tech Report NMFS 90:511-512

Castro JI (1987) The position of sharks in marine biological communities: an overview. In: Cook S (ed) Sharks, an inquiry into biology, behavior, fisheries, and use. Oregon State University Extension Service, Corvallis, p 11-17

Castro JI (1993) The shark nursery of Bulls Bay, South Carolina, with a review of the shark nurseries of the southeastern coast of the United States. Environ Biol Fish 38: 37-48

Castro JI (1996) Biology of the blacktip shark, Carcharhinus limbatus, off the southeastern United States. Bull Mar Sci 59:508-522

Castro JI (2000) The biology of the nurse shark, Ginglymostoma cirratum, off the Florida east coast and the Bahama Islands. Environ Biol Fish 58:1-22

Clark E, von Schmidt K (1965) Sharks of the central gulf coast of Florida. Bull Mar Sci 15:13-83

>Cortés E (2000) Life history patterns and correlations in sharks. Rev Fish Sci 8:299-344

Cortés E, Gruber SH (1990) Diet, feeding habits and estimates of daily ration of young lemon sharks, Negaprion brevirostris. Copeia 1:204-218

DeAngelis BM (2006) The distribution of elasmobranchs in St. Thomas and St. John, United States Virgin Islands with an emphasis on shark nursery areas. MSc thesis, University of Rhode Island, Kingston

Driggers WB, Carlson JK, Cullum B, Dean JM, Oakley D, Ulrich G (2004) Age and growth of the blacknose shark, Carcharhinus acronotus, in the western north Atlantic ocean with comments on regional variation in growth rates. Environ Biol Fish 71:171-178 
Gruber SH, Nelson D, Morrissey J (1988) Patterns of activity and space utilization of lemon sharks, Negaprion brevirostris, in a shallow Bahamian lagoon. Bull Mar Sci 43: 61-76

- Gruber SH, DeMarignac JRC, Hoenig JM (2001) Survival of juvenile lemon sharks at Bimini, Bahamas, estimated by mark-depletion experiments. Trans Am Fish Soc 130: 376-384

Heithaus MR (2001) The biology of tiger sharks, Galeocerdo cuvier, in Shark Bay, Western Australia: sex ratio, size distribution, diet, and seasonal changes in catch rates. Environ Biol Fish 61:25-36

Henningsen AD (2000) Notes on reproduction in the southern stingray, Dasyatis americana (Chondrichthyes: Dasyatidae), in a captive environment. Copeia 3:826-828

> Heupel MR, Hueter RE (2002) Importance of prey density in relation to the movement patterns of juvenile blacktip sharks (Carcharhinus limbatus) within a coastal nursery area. Mar Freshw Res 53:543-550

> Heupel MR, Simpfendorfer CA (2002) Estimation of mortality of juvenile blacktip sharks, Carcharhinus limbatus, within a nursery area using telemetry data. Can J Fish Aquat Sci 59:624-632

Heupel MR, Simpfendorfer CA, Hueter RE (2004) Estimation of shark home ranges using passive monitoring techniques. Environ Biol Fish 71:135-142

> Heupel MR, Carlson JK, Simpfendorfer CA (2007) Shark nursery areas: concepts, definitions, characterization and assumptions. Mar Ecol Prog Ser 337:287-297

Hoenig JM, Gruber SH (1990) Life history patterns in the elasmobranchs: implications for fisheries management. NOAA Tech Report NMFS 90:1-16

Hoese HD (1962) Sharks and rays of Virginia's seaside Bays. Chesapeake Sci 3:166-172

Hoffmayer ER, Parsons GR (2003) Food habits of three shark species from the Mississippi sound in the northern Gulf of Mexico. SE Nat 2:271-280

Holden MJ (1974) Problems in the rational exploitation of elasmobranch populations and some suggested solutions. In: Hardin-Jones FR (ed) Sea fisheries research. John Wiley and Sons, New York, p 117-137

Kohler NE, Casey JG, Turner PA (1998) NMFS Cooperative Tagging Program, 1962-1993: An atlas of shark tag and recapture data. Mar Fish Rev 60:1-87

Maunder MN, Punt AE (2004) Standardizing catch and effort data: a review of recent approaches. Fish Res 70: 141-159

McCandless CT (2007) Preface. Am Fish Soc Symp 50:vii-ix

McCandless CT, Pratt HL, Kohler NE, Merson RR, Recksiek CW (2007) Distribution, localized abundance, movements, and migrations of juvenile sandbar sharks tagged in Delaware Bay. Am Fish Soc Symp 50:45-62

Merson RR (1998) Nursery grounds and maturation of the sandbar shark in the western North Atlantic. PhD thesis, University of Rhode Island, Kingston

Merson RR, Pratt HL (2001) Distribution, movements and growth of young sandbar sharks, Carcharhinus plumbeus, in the nursery grounds of Delaware Bay. Environ Biol Fish 61:13-24

Meyers S (1994) Cooperative Fishery Statistics Program Annual Summary Report, April 1993-March 1994

Morrissey JF, Gruber SH (1993) Habitat selection by juvenile lemon sharks, Negaprion brevirostris. Environ Biol Fish 38:311-319

Musick JA (1999) Ecology and conservation of long-lived marine animals. In: Musick JA (ed) Life in the slow lane: ecology and conservation of long-lived marine animals. Am Fish Soc Symp 23, Bethesda, MD, p 1-10

NMFS (1999) Final Fishery Management Plan for Atlantic Tuna, Swordfish and Sharks. NOAA, NMFS, Office of Sustainable Fisheries, Highly Migratory Species Management Division, Silver Spring, MD

NMFS (2006) Final Consolidated Atlantic Highly Migratory Species Fishery Management Plan. NOAA, NMFS, Office of Sustainable Fisheries, Highly Migratory Species Management Division, Silver Spring, MD

NOAA (2001) National Ocean Service, National Centers for Coastal Ocean Science Biogeography Program. Benthic Habitats of Puerto Rico and the U.S. Virgin Islands (CDROM).

Pratt HL, Casey JG (1990) Shark reproductive strategies as a limiting factor in directed fisheries, with a review of Holden's method of estimating growth-parameters. NOAA Tech Report NMFS 90:97-109

Pratt HL, Otake T (1990) Recommendations for work needed to increase our knowledge of reproduction relative to fishery management. NOAA Tech Report NMFS 90:509-510

Rogers C, Beets J (2001) Degradation of marine ecosystems and decline of fishery resources in marine protected areas in the US Virgin Islands. Environ Conserv 28:312-322

Rogers C, Miller J (2006) Permanent 'phase shifts' or reversible declines in coral cover? Lack of recovery of two coral reefs in St. John, US Virgin Islands. Mar Ecol Prog Ser 306:103-114

Rountree RA, Able KW (1996) Seasonal abundance, growth, and foraging habits of juvenile smooth dogfish, Mustelus canis, in a New Jersey estuary. Fish Bull, US 94:522-534

Simpfendorfer CA, Milward NE (1993) Utilization of a tropical bay as a nursery area by sharks of the families Carcharhinidae and Sphyrnidae. Environ Biol Fish 37: 337-345

Smith SE, Au DW, Show C (1998) Intrinsic rebound potentials of 26 species of Pacific sharks. Mar Freshw Res 49:663-678

Snelson FF Jr, Mulligan TJ, Williams SE (1984) Food habits, occurrence, and population structure of the bull shark, Carcharhinus leucas in Florida coastal lagoons. Bull Mar Sci 34:71-80

Springer S (1967) Social organization of shark populations. In: Gilbert PW, Mathewson RF, Rall DP (ed) Sharks, skates and rays. John Hopkins Press, Baltimore, MD, p 149-174

Stevens JD (1984) Life-history and ecology of sharks at Aldabra Atoll, Indian Ocean. Proc R Soc Lond B Biol Sci 222:79-106

Stone RB, Bailey CM, McLaughlin SA, Mace PM, Schulze MB (1998) Federal management of US Atlantic shark fisheries. Fish Res 39:215-221

Tobias W (1997) State/Federal Cooperative Fishery Statistics Program Three-Year Summary Report, 1 April 1994-31 March 1997

Tobias W (2000) U.S Virgin Islands/National Marine Fisheries Service Inter-jurisdiction Fisheries Program Final (Completion) Report, 1 October 1997-30 September 2000

Tobias W, Meyers S, Kojis B, Dalmida-Smith B (1996) The determination of mangrove habitat for nursery grounds of recreational fisheries in St. Croix. Final Report: Recreational Fisheries Habitat Assessment, Period: 1 October 1991-30 September 1995

Tobias W, Gomez R, Mateo I, Kojis B (2000) U.S. Virgin Islands State/Federal Cooperative Statistics Program Summary Report, 1 April 1997-31 March 1999

Zar JH (1996) Biostatistical analysis, 3rd edn. Prentice Hall, Upper Saddle River, NJ 